\title{
Educação Popular em Saúde e democracia
}

\author{
Popular Education in Health and democracy
}

Educación Popular en Salud y democracia

Noemi Margarida Krefta(a)

A Constituição Federal de 1988 tem trazido avanços importantes para população, dentre elas, a conquista de uma política de saúde pública denominada Sistema Único de Saúde (SUS). Sua regulamentação traz uma série de complementos que vão desde estrutura, funcionamento, controle e participação social...

Os movimentos e organizações são convocados, por setores do governo, a construir proposta de ações a ser desenvolvidas como políticas públicas, mas temos que fazer uma avaliação do quanto isso tem contribuído para a organização e controle social, bem como se não estamos assumindo o papel do governo nos serviços que devem ser públicos. Esses espaços têm ocupado as agendas das lideranças e, se não tiverem um cuidado, podem distanciar-se de suas bases.

Com a eleição do governo Lula, houve uma expectativa de participação da sociedade e avanço nas conquistas, principalmente para a população mais necessitada. Os movimentos populares, ansiosos por um novo governo, viram mais uma vez se firmarem acordos com o agronegócio e com o grande capital em detrimento das lutas sociais.

A "democracia" de efetivar espaços de participação e controle social tem aumentado a demanda de lideranças para dar conta dos espaços propostos, onde as discussões e propostas de efetivação de políticas vão ao encontro dos anseios das bases - discussões estas que têm sido acaloradas pela firme postura de levar as pautas de lutas de suas organizações e poder elencar alguns avanços reais.

Os limites com que se constroem as propostas de uma política de saúde, mesmo por dentro do SUS, têm mostrado que, dentro do sistema de sociedade no qual vivemos, podem-se fazer alguns ajeitamentos, os quais, na maioria, não saem do papel, pois os gestores estão desinformados e não têm interesse em construir ações que vão ao encontro dos anseios e necessidades da população ou usuários.

A Educação Popular em Saúde, para nós, tem sido base para a promoção da saúde e o cuidado com a vida no ambiente em que vivemos. Não se pode ter saúde em um ambiente desequilibrado, doente, sem o cuidado com a biodiversidade. Fazer o ser humano se entender no espaço onde está, torná-lo consciente e responsável por seus atos e junto aos que o cercam, é antes de tudo educar-se e transmitir os conhecimentos adquiridos aos demais.

Essa educação se faz de forma milenar, sem grandes teorias, mas sim na prática e, também, sem muita síntese, o que tem provocado inquietações. Além disso, os movimentos vêm buscando uma forma de ressignificar essa educação

(a) Movimento de Mulheres Camponesas. Linha Barra Grande, Palma Sola, SC, Brasil. 89985-000. noemikrefta@yahoo. com.br 
para renovar as energias junto às bases, e fortalecer seu trabalho de renovar a indignação das massas, para juntá-las e levar às ruas, demonstrando sua força e vigor na busca de seus direitos.

No modelo de agricultura convencional e altamente químico, manter a firmeza num projeto de agricultura camponesa e agroecológico é ter muita teimosia e convicção de que o cuidado com a saúde implica em uma educação libertadora e consciente de que a vida está acima de tudo e que não é mera mercadoria.

Essa convicção tem levado a uma constante luta de embate com o agronegócio, que quer continuar a impor seu modelo baseado no lucro acima de tudo, e que, para tal, faz acordos, ocupa os espaços de poder para manipular e criar mecanismos que legitimem suas ações em favor da ordem e democracia por eles impostas.

Nessa sociedade, fala-se muito em democracia participativa, mas temos que avaliar até onde de fato se tem direito de decidir sobre o que é anseio das massas, ou de apenas opinar sobre o que é melhor para elas.

Aparentemente, os instrumentos de participação e controle social deveriam dar conta da participação paritária da população, seja nos momentos de definição das ações, seja na fiscalização das ações, que vão sendo executadas pelos gestores e prestadores de serviços, mas os ajustes, para que predominem suas intenções, fazem com que camufladamente os acordos se façam por debaixo dos panos e os usuários ficam em menor proporção.

A Educação Popular em Saúde continua sendo um anseio dos movimentos em trazê-la como parte nas políticas públicas e não como um caminho em separado, sem visibilidade e valorização por parte dos gestores que continuam tratando a saúde como simplesmente cuidar dos agravos e algumas prevenções.

Perceber as angústias do povo é mais fácil para quem conhece a realidade onde pisa, interage e busca entender o jeito de o povo se organizar em seus grupos, comunidades, cidades, seus costumes, cultura, enfim, seu modo de vida. Mas isso só acontece quando se adota a metodologia de Educação Popular, o que os movimentos mantêm vivo na sua atuação.

Fazer com o povo não permite se colocar no meio e agir como alguém acima desse povo. Precisa estar junto e se prontificar a buscar brechas para termos alguns avanços dentro dessa conjuntura adversa que privilegia as classes abastadas.

Sem luta não haverá conquista, nenhum governo dará ao povo seus direitos sem pressão e mobilização popular. Portanto, a democracia, para o movimento social e popular, é organizar-se e preparar sua base para a luta por seus direitos e vida digna. 